УДК 331.104

\title{
НЕКОТОРЫЕ ПОЛИТИКО-ЭКОНОМИЧЕСКИЕ АСПЕКТЫ ИССЛЕДОВАНИЯ ТРУДОВЫХ ОТНОШЕНИЙ В РЕСПУБЛИКЕ БЕЛАРУСЬ НА СОВРЕМЕННОМ ЭТАПЕ
}

\author{
Т.В. СЕРГИЕВИЧ \\ аспирант кафедры «Экономика и право» \\ Белорусского национального технического университета, г. Минск
}

\begin{abstract}
Аннотация
Статья посвящена исследованию трудовых отношений в Республике Беларусь на современном этапе. Представлены основные тенденции в области образовательного уровня занятых, что оказывает существенное влияние на устойчивое развитие национальной экономики.

Ключевые слова: трудовые отношения, занятость, уровнь занятости, уровень образования, устойчивое развитие.
\end{abstract}

Abstract

The article is devoted to research of labor relations in the Republic of Belarus at the present stage. There were marked out the main trends in the educational level of employees, which have a significant impact on the sustainable development of the national economy.

Key words: labor relations, employment, employment, level of education, sustainable development.

\section{ВВЕДЕНИЕ}

Реализация модели устойчивого инновационного социально-экономического развития Республики Беларусь во многом зависит от теоретического и практического решения проблемы труда. Труд рассматривается как основа жизнедеятельности человека, как фактор производства, как источник прибыли, как источник удовлетворения общественных и личных потребностей, как условие человеческой жизни, как источник повышения эффективности и конкурентоспособности экономики. Научно-технический прогресс, влияющий на производство, развитие форм человеческого капитала и общая трансформация социально-экономических систем модифицирует характерное для предыдущих эпох содержание и характер труда и систему трудовых отношений. Для решения проблемы труда и управления трудом, необходимо определить, что мы будем понимать под категориями «труд» и «трудовые отношения». Проблемы труда, занятости, рынка труда являются объектом ряда теоретических и прикладных разработок. Экономисты, философы, социологи различных исторических периодов, представители разных научных школ исследовали труд и занятость: Дж. Кейнс, Ф. Кенэ, Т. Мальтус, К. Маркс, А. Маршалл, Дж. Милль, У. Петти, Д. Рикардо, А. Смит, М. Фридмен, Ф. Хайек, Ф. Энгельс и др. Непосредственно трудовые отношения в экономической науке до относительно недавнего времени не получали должного внимания. Они исследованы в работах ряда белорусских ученых: Е.В. Ванкевич, Л.П. Васюченок, Н.В. Герасимов, Т.В. Кузьмицкая, Н.В. Маковская, А.П. Морова, П.Г. Никитенко, С.Ю. Солодовников, которым удалось выделить трудовые отношения в системе экономических отношений, раскрыть их структуру, виды и функциональную роль в социально-экономических системах. Вместе с тем в настоящее время зачастую работы по исследованию трудовых отношений сводятся к анализу правового аспекта отношений 
«работник-наниматель», что имеет огромное практическое значение в ущерб гносеологической ценности.

\section{РЕЗУЛЬТАТЫ И ИХ ОБСУЖДЕНИЕ}

Труд, как известно, - комплексная категория, которая включает в себя множество различных аспектов, изучаемых в рамках ряда наук: в социологии, психологии, антропологии, менеджменте, экономике, и рассматриваемых под разными углами. Человек, как элемент конкретной общественно-экономической формации, обеспечивает ее функционирование и воспроизводство общества в целом и субъектов, в него входящих, в частности, посредством своего труда, являющегося основой совокупного общественного производства. В общественном производстве Н.В. Герасимов выделял четыре относительно обособленные сферы, которые взаимосвязаны, взаимообусловлены и взаимозависимы: материальное производство, духовное производство, социальное производство, производство общественного человека [1, с. 7-10]. Интеграция этих сфер означает невозможность функционирования одной без результатов труда, созданных в другой сфере. Сфера материального производства обеспечивает физическую жизнь общества (удовлетворение физиологических потребностей человека), а также создает материальную базу, необходимую в других сферах общественной жизни и совокупного общественного производства. Духовное производство знаний, информации, нравственных, мировоззренческих, этических и других ценностей служит для «реализации интеллектуальных и психических способностей» человека [1, с. 8]. Именно сфера духовного производства обеспечивает развитие и прогресс человеческого общества, ведь «только разум и научный труд являются той фундаментальной генетической основой важнейшим человеческим свойством, которое позволяет универсально осуществлять реализацию монистического принципа субстационального единства материального и нематериального социально ориентированного воспроизводства и всех его социальноэкономических форм» [2, с. 121]. Социальное производство обеспечивает функционирование общества путем производства, развития, поддержания, воспроизводства системы общественных отношений (как взаимосвязей между элементами системы, без которых не способна существовать ни одна система). Сфера производства общественного человека обеспечивает «производство себе подобных, целесообразное развитие задатков и трансформация их в реальные трудовые, социальные и другие способности, воспитание индивидов как граждан, субъектов общественных отношений» $[1$, с. 8]. Сфера производства общественного человека формирует работников для функционирования других сфер. Сфера материального производства обеспечивает материальновещественную основу для воспроизводства человека как биологического существа, духовное производство и сфера производства общественного человека обеспечивают воспроизводство человека как существа социального. Человек как существо социальнобиологическое обладает определенным набором физиологических свойств, здоровьем как важным условием способности к труду. От уровня этих качественных характеристик зависит возможность и эффективность труда человека, продолжительность его трудовой жизни, а также дальнейшее воспроизводство человеческих ресурсов. Человек как существо собственно социальное обладает определенным уровнем нравственности, гражданской ответственности, моральными характеристиками. Эти составляющие определяют качество человеческого капитала, являющего важным фактором развития экономики на современном этапе, который к тому же обладает уникальным свойством безграничного роста. Инструментами расширения воспроизводства человеческого капитала, на наш взгляд, является инвестирование средств в человеческий капитал государством и негосударственными общественными фондами и организациями посредством создания общественных благ, создание условий для инвестиций в человеческий 
капитал предприятиями, а также инвестирование средств в человеческий капитал домохозяйствами и отдельными гражданами благодаря стимулированию их к получению образования, саморазвитию, пропаганде здорового образа жизни и занятий спортом, формированию системы моральных ценностей, нравственному воспитанию нации.

Специализация производства обусловлена историческими и природными факторами, а также во многом зависит от уровня относительной обеспеченности национального хозяйства другими факторами производства. Учитывая тот факт, что уровень развития страны во многом зависит от того, насколько экономика способна адаптироваться к мировой конъюнктуре, а также к тем изменениям, которые определяет научнотехнический прогресс, в Республике Беларусь одной из стратегических целей стабильного экономического развития выступает значительное расширение выпуска конкурентоспособной высокотехнологичной продукции, а также увеличение удельного веса наукоемкой продукции в общем объеме выпуска и экспорта [3]. Достижение этой цели в совокупности с решением других стратегических задач позволит обеспечить экономическую безопасность государства. Производство высокотехнологичной продукции может быть реализовано лишь при использовании сравнительных преимуществ в виде человеческого капитала, в частности высокой квалификации труда, а также реальном научном потенциале. Как отмечает В.А. Перепелкин, «национальные хозяйственные системы, насыщенные научным персоналом и высококвалифицированной рабочей силой, структурно подвижны и нуждаются лишь в некотором содействии со стороны государства очередной отраслевой перестройке» [4, с. 122]. Профессиональная и территориальная мобильность - важный показатель качества трудовых ресурсов. Трудовые ресурсы, обладающие низким уровнем квалификации, занятые ручным трудом, как правило, обладают низким уровнем мобильности. Это связано, в первую очередь, с низким уровнем мотивации из-за деформированной системы потребностей, с нежеланием обучаться, с нежеланием возвращаться на производство в случае потери работы. Трудовые ресурсы Республики Беларусь характеризуются довольно высоким уровнем образования. Основные тенденции, характеризующие уровень образования занятых в экономике представлены на рисунке 1.

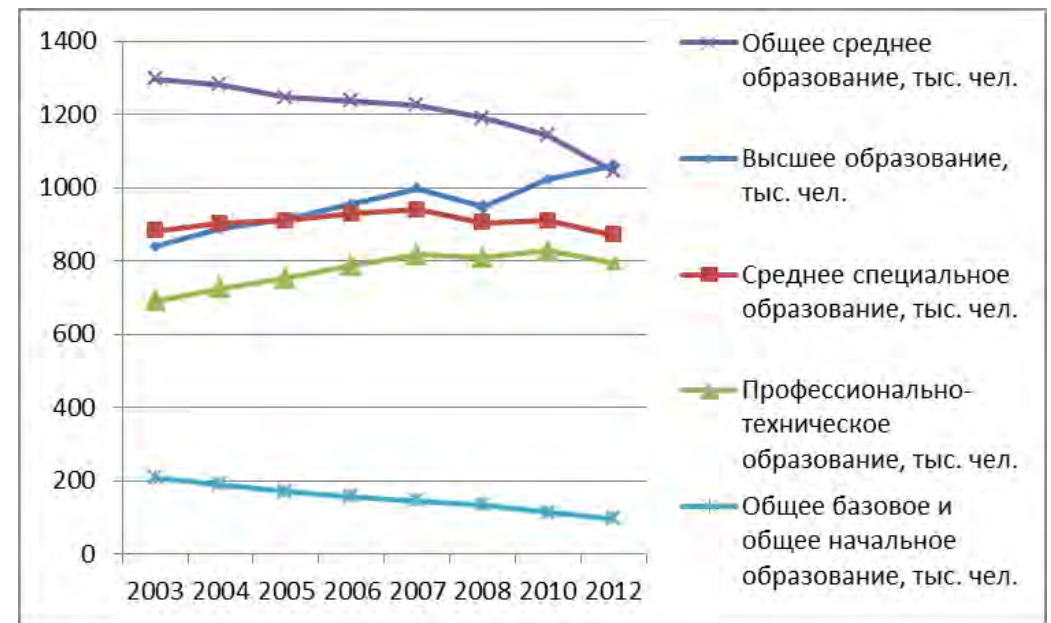

Рисунок 1 - Уровень образования занятых в Республике Беларусь, 2003-2012 гг.

Источник: составлено автором по [5, 6, 7].

На рисунке прослеживается тенденция уменьшения количества людей, имеющих общее среднее, общее базовое и общее начальное образование, и одновременный скачкообразный рост количества людей с высшим образованием, даже несмотря на общее снижение числа занятых вследствие таких демографичеких проблем, как старение и сокращение населения. Для более наглядного сравнительного отражения 
тенденции увеличения общего уровня образованности ниже представлены диаграммы (рисунок 2, 3), отражающие количество занятых в экономике по уровню образования в процентном соотношении.

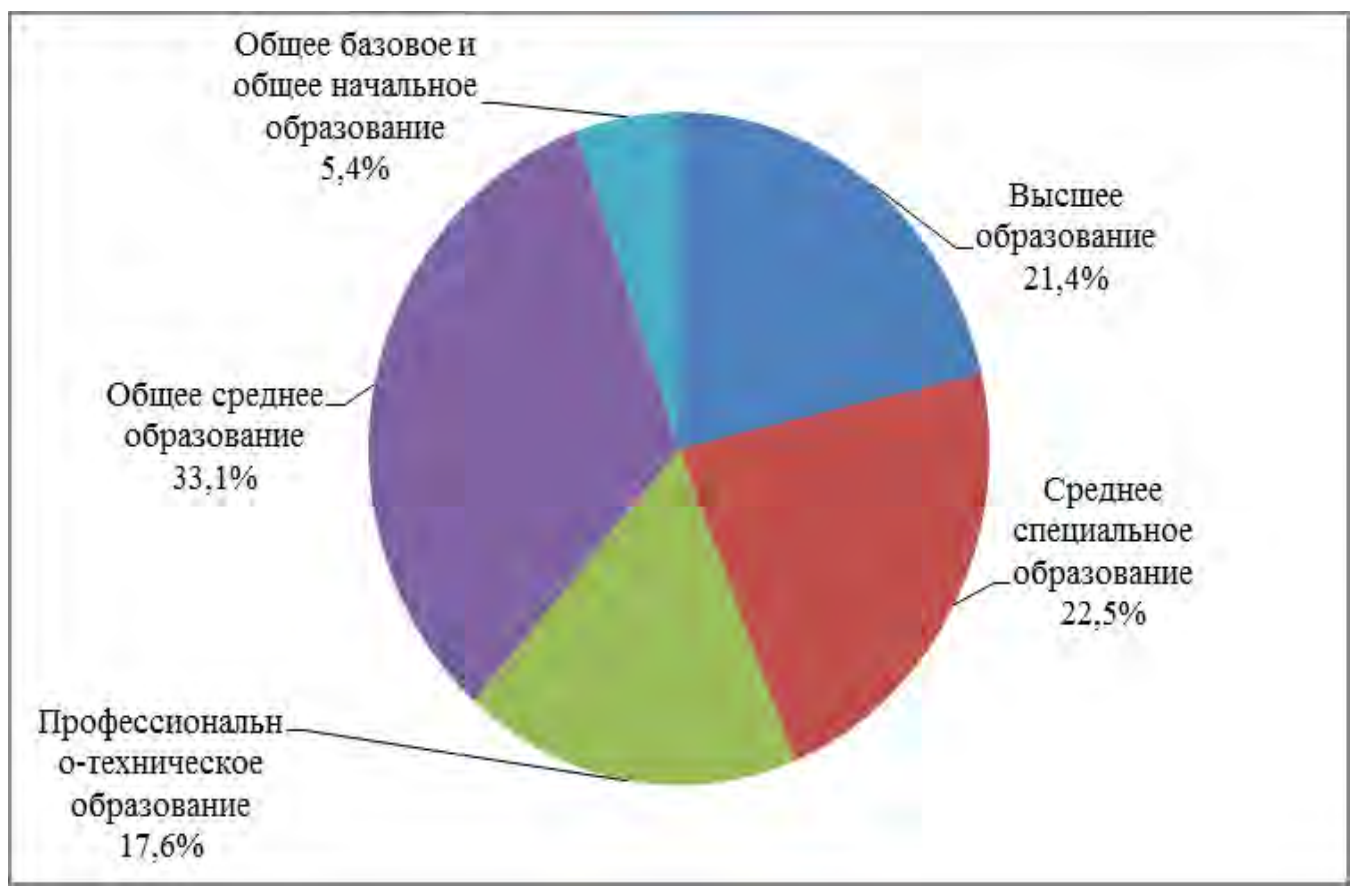

Рисунок 2 - Уровень образования занятых в Республике Беларусь, 2003 г. Источник: составлено автором по [5, 6, 7].

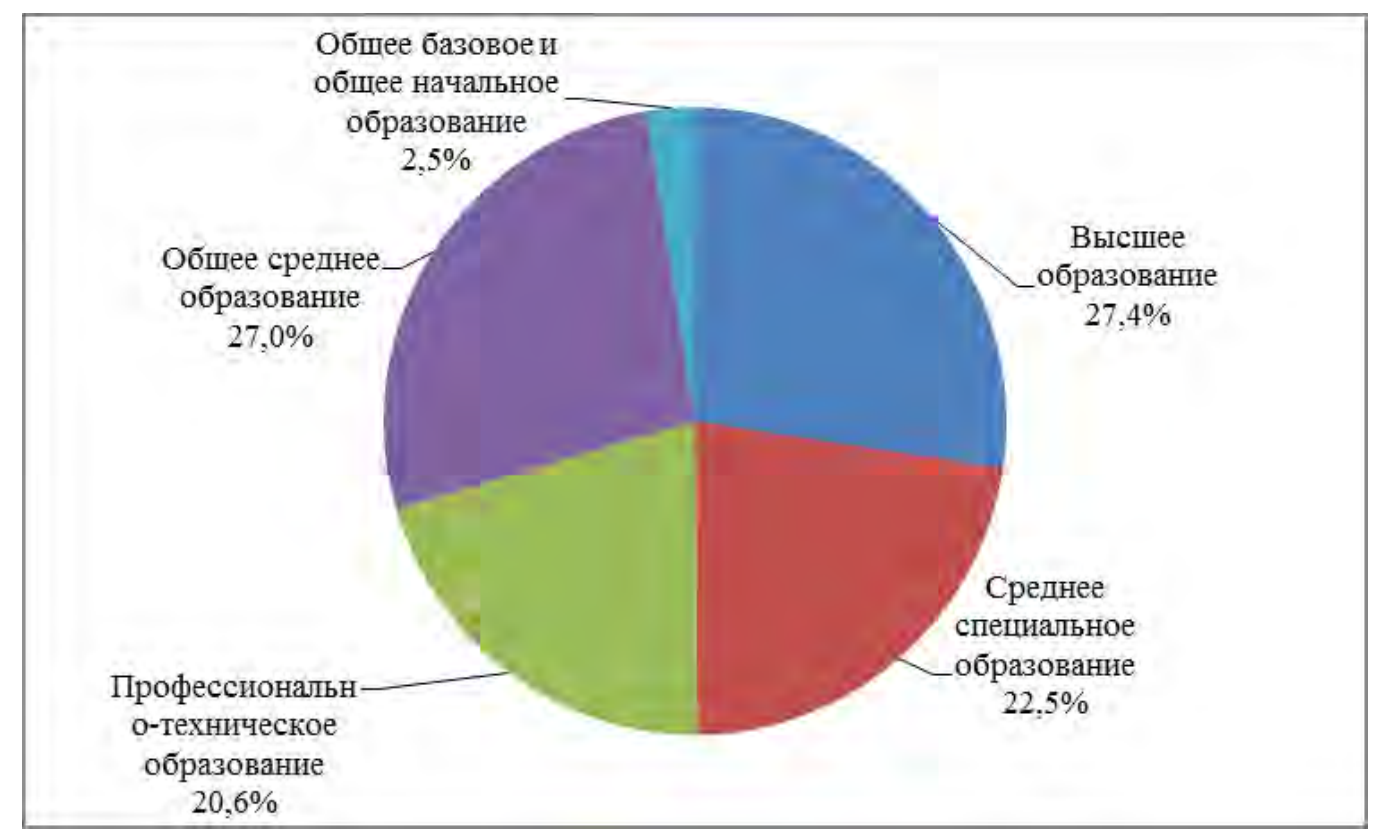

Рисунок 3 - Уровень образованности занятых в Республике Беларусь, 2012 г. Источник: составлено автором по [5, 6, 7].

Доля занятых лиц, имеющих высшее образование, за 10 лет выросла на 6 \%. По всей видимости, такая тенденция будет сохраняться и в дальнейшем. Данный показатель является важным, т.к. в результате увеличения удельного веса образованных и высококвалифицированных кадров, накопления социального капитала и элементов общей и профессиональной культуры происходит повышение творческого (в том числе научного, технического) потенциала трудящихся. 
Другим показателем, отражающим реальный научный потенциал, является количество персонала, занятого научными исследованиями и разработками. Под последним будем понимать «совокупность лиц, чья творческая деятельность, осуществляемая на систематической основе, направлена на увеличение суммы научных знаний и поиск новых областей применения этих знаний, а также занятых оказанием прямых услуг, связанных с выполнением научных исследований и разработок» [7, с. 149]. В Республике Беларусь число таких занятых в 2014 году составило 27208 человек (0,003 \% от численности населения). По этому показателю наша страна уступает странам-лидерам Западной Европы таким, как Германия $(0,0072 \%)$, Нидерланды $(0,0069 \%)$, Соединенное Королевство $(0,0057 \%)$. Уступая России $(0,005 \%)$ и находясь примерно на одном уровне с Украиной $(0,003 \%)$, Республика Беларусь опережает партнеров по Евразийскому экономическому союзу Казахстан $(0,0012 \%)$ и Армению $(0,0019 \%)$, а также Китай $(0,0023 \%)$. Однако если оперировать цифрами, отражающими количество персонала, занятого научными исследованиями и разработками, а не процентным соотношением, то ситуация выглядит значительно хуже. Так, например, Китаю наша страна уступает более чем в 100 раз. Более того, в отличие от большинства развитых и развивающихся стран, в которых количество персонала, занятого научными исследованиями и разработками, с каждым годом растет (так, в период с 2005 по 2012 годы в Китае в 2,3 раза, в Германии и Нидерландах - в 1,2 раза), в Республике Беларусь в последние годы оно остается относительно стабильным [8]. Более того, если выбрать более длинный отрезок времени (рисунок 4), то можно проследить тенденцию к уменьшению рассматриваемой категории лиц.

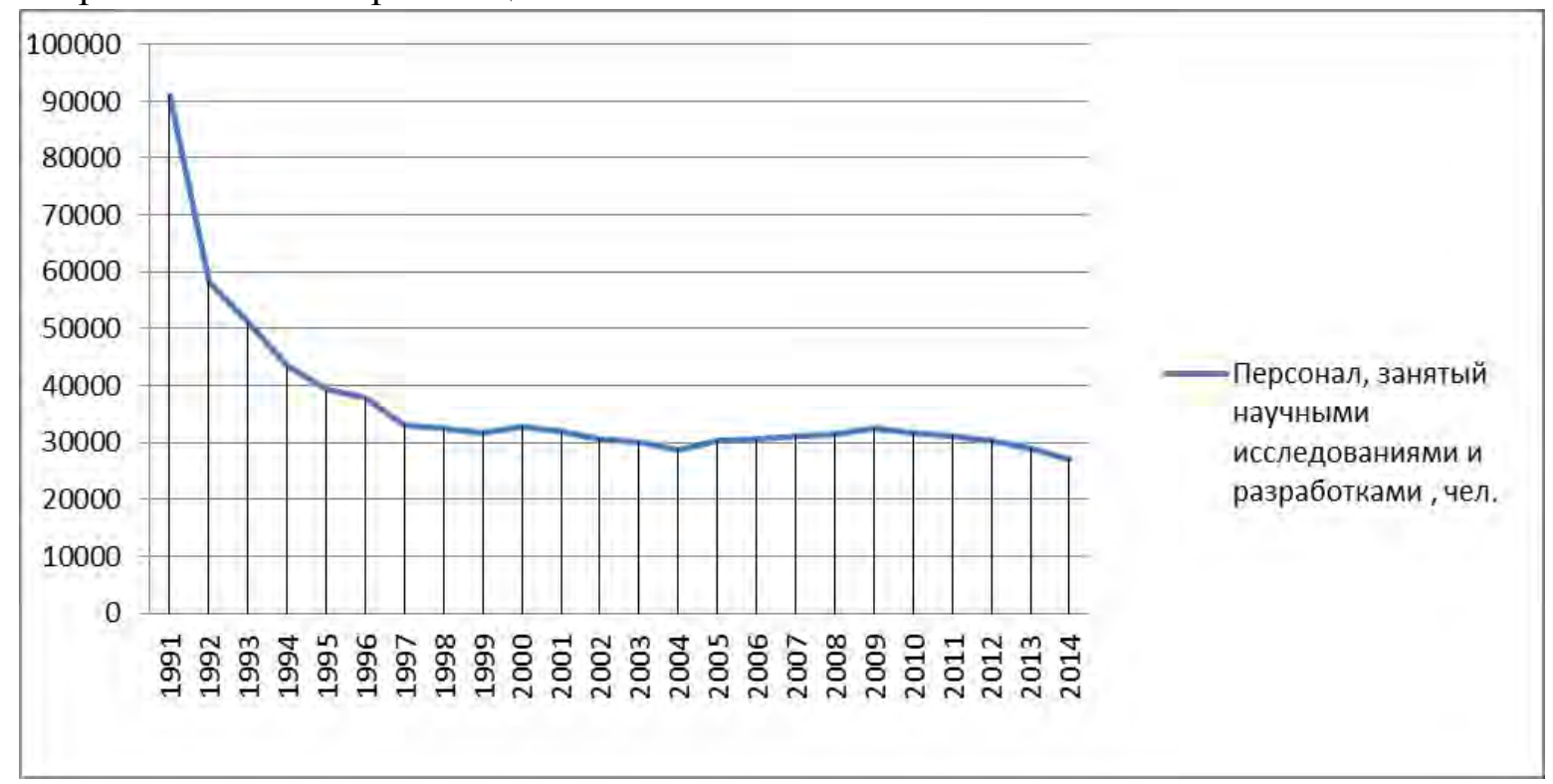

Рисунок 4 - Персонал, занятый научными исследованиями и разработками, 1996-2014 гг.

Источник: составлено автором по [8, 9, 10, 11$]$.

Вместе с тем наблюдается старение научных кадров, что само по себе является проблемой, т.к. не удается обеспечить их расширенное воспроизводство. Отражение данных, подтверждающих обозначенную проблему, представлено на рисунках 5, 6. 


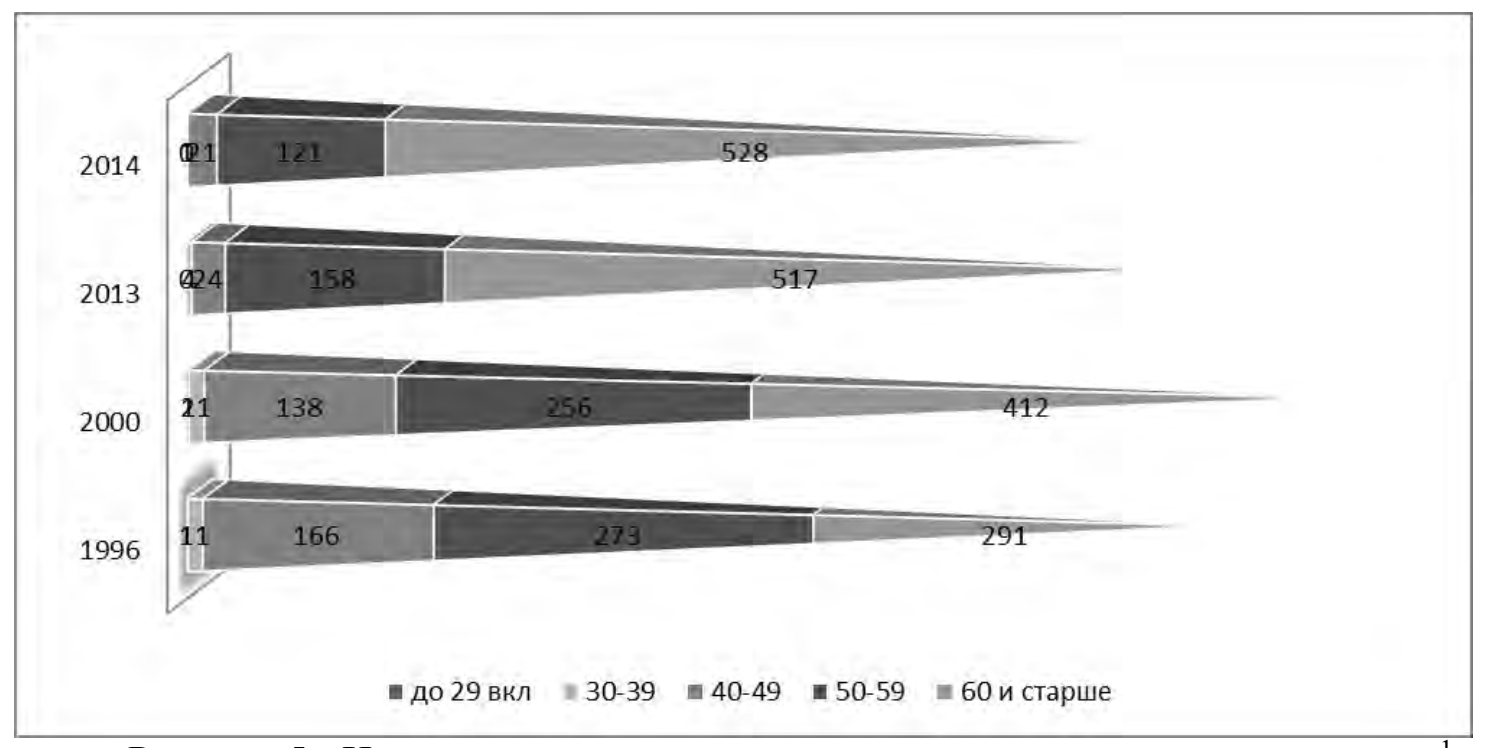

Рисунок 5 - Исследователи, имеющие ученую степень доктора наук, чел. Источник: составлено автором по [8].

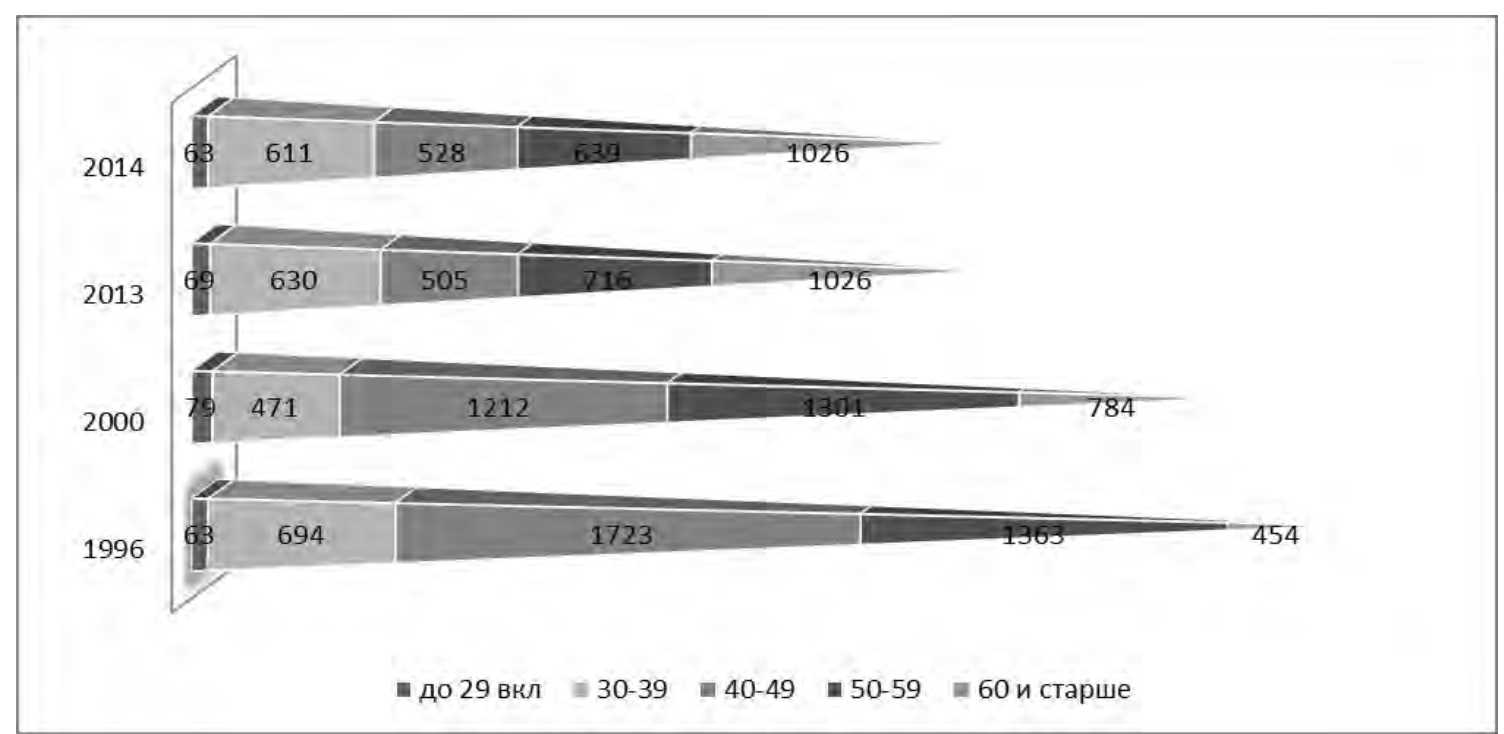

Рисунок 6 - Исследователи, имеющие ученую степень кандидата наук, чел. Источник: составлено автором по [8]. ${ }^{2}$

При сохранении тенденции к уменьшению общего числа исследователей ${ }^{3}$, имеющих ученую степень, увеличивается число и доля тех, чей возраст превышает 60 лет, и резко уменьшается число исследователей моложе этого возраста (за исключением числа исследователей, имеющих ученую степень кандидата наук, чей возраст составляет 30-39 лет). Обозначенная проблема негативно скажется на развитии экономики в долгосрочной перспективе, или, говоря иначе, не позволит получить тех преимуществ, которые могли бы быть получены при развитии обратного сценария, ведь устойчивое развитие экономики на современном этапе может быть обеспечено при условии объедине-

\footnotetext{
${ }^{1}$ Примечание. Данные за 1996 год отражают число исследователей по возрастным категориям: до 30 (включительно), 31-39.

2 Примечание. Данные за 1996 год отражают число исследователей по возрастным категориям до 30 (включительно), 31-39.

${ }^{3}$ Исследователи - работники, профессионально занимающиеся научными исследованиями и разработками и непосредственно осуществляющие создание новых знаний, продуктов, процессов, методов и систем, а также управление указанными видами деятельности [8].
} 
ния усилий науки и производства в целях недопущения попадания страны в ловушку «догоняющего развития».

Все сферы совокупного общественного производства в своем единстве, продиктованном, во-первых, необходимостью в постоянном обмене результатами труда, а вовторых, тем фактом, что в реальном мире они практически не встречаются в «чистом» виде, сохраняют некую относительную автономность и противоречивость. Такая дифференциация позволяет выделить виды и формы труда, типы работников, особенности содержания труда. В каждой из сфер производства некий продукт является результатам труда как целесообразной деятельности, направленной на создание материальных и духовных благ. Однако в целях сужения объекта исследования разграничим понятие просто «полезной деятельности» и понятие «труд». Принимая во внимание тот факт, что «способность к труду является основным, но не единственным человеческим свойством» [2, с. 121], а сам труд является сложным, комплексным, системным образованием, «которое экономической наукой рассматривается через систему взаимодействия прежде всего двух типов комплексных противоречивых условий - экономических и социальных» [2, с. 121], понимая под деятельностью «специфически человеческую форму активного отношения к окружающему миру, содержание которой составляет его целесообразное изменение и преобразование» $[12$, с. 180], можно сказать, что не всякая полезная деятельность является трудом, а общественная полезность является необходимым, но не достаточным условием отнесения деятельности к труду. Как сфера жизнедеятельности человека труд охватывает множество проявлений активности, характеризуемой рядом критериев: целесообразность, осознанность, результативность, направленность на создание материальных и духовных благ, энергозатратность, наличие механизмов внешнего и (или) внутреннего контроля. Для исследований труда в рамках экономической науки обязательными критериями отнесения того или иного вида деятельности к труду, помимо названных, является создание потребительных стоимостей. На выделении этого критерия основано определение категории «труд», данное К. Марксом и не теряющего своей гносеологической актуальности и сегодня: «труд это процесс, совершающийся между человеком и природой, т.е. целесообразная деятельность человека, в процессе которой он своей собственной деятельностью опосредует, регулирует и контролирует обмен веществ между собой и природой, создает необходимые потребительные стоимости» [13, с. 188]. Труд, выступающий в качестве фактора производства, направлен на создание потребительных стоимостей. Эта направленность человеческой деятельности позволяет отграничить такие виды деятельности, как ведение домашнего хозяйства, направленное на удовлетворение личных потребностей, криминальная деятельность, направленная не на создание, а присвоение потребительной стоимости, хобби, волонтерскую деятельность и другие виды деятельности. Речь идет не о том, что перечисленные виды деятельности не являются трудом, а о том, что предпринимается попытка отграничить тот труд и те трудовые отношения, которые нас интересуют в рамках настоящего исследования и которые преобладают в системе экономических отношений на современном этапе социально-экономического развития нашего государства.

Под трудовыми отношениями мы будем понимать «отношения, которые возникают и устанавливаются между субъектами в процессе трудовой деятельности при создании материальных средств и благ, а также услуг необходимых для удовлетворения экономических потребностей и нужд общества и его членов с целью обеспечения их жизненности» $[14$, с. 8]. Такое понимание трудовых отношений основывается на взгляде на экономическую систему как на «единый, устойчивый, организационно оформленный, относительно самостоятельный, материально-общественный комплекс, в пределах которого осуществляются внутренне взаимосвязанное производство, присвоение 
и социально значимое потребление материальных средств и благ для обеспечения физической жизни общества, также для создания материальной базы, необходимой во всех остальных сферах общественной жизни» [1, с. 25-26]. Как и другие объекты экономического анализа, трудовые отношения в чистом виде в реальной действительности не могут функционировать, однако в целях научного анализа допустимо отделить их от других блоков экономических отношений (отношений собственности, потребностных отношений, статусных отношений и отношений определения социальноэкономического поведения субъектов) и социальных отношений (семейных, возрастных, религиозных, политических). Такое понимание позволяет отграничить труд от потребительской деятельности, обозначая целесообразность, осознанность и направленность труда. Трудовые отношения, как и любая другая система (или, в данном случае подсистема экономических отношений), имеет свою структуру, которая предполагает наличие субъекта трудовых отношений как носителя активности, объекта трудовых отношений как то, на что направлена эта активность, а также самой активности как взаимосвязи между субъектом и объектом трудовых отношений и между субъектами. Такой подход к рассмотрению структуры системы трудовых отношений позволяет говорить о том, что последние включают в себя субъект-объектные отношения, межсубъектные отношения, а также внутрисубъектные отношения. Последние определяют специфичность труда, которая заключается в том, что субъект в процессе выполнения труда сам становится объектом, в случае, если «он направляет активность на собственное «я», на самопознание ил самоизменение самого себя» [15, с. 23]. Следует, однако, добавить, что в процессе труда доля активности в той или иной степени всегда направлена на самого себя, т.к. реализовывая свои навыки и умения в процессе выполнения трудовой деятельности, человек совершенствуется в профессиональном плане, что позитивно влияет на его социальное развитие и, как следствие, развитие общества в целом. Об этом писал еще К. Маркс, отмечая, что «воздействуя ... на внешнюю природу и изменяя ее, он в то же время изменяет свою собственную природу» [13, с. 188]. Такое понимание диалектики трудовых отношений позволяет согласиться с выделением основной социально-экономической функции трудовых отношений как «обеспечения производительной трудовой деятельности по созданию материальных средств и услуг, необходимых для обеспечения физической жизненности человека и общества, и развитие трудовых и других его способностей, обеспечивающих разностороннее развитие, самоутверждение и максимальную выживаемость» [15, с. 13]. Другими элементами структуры трудовых отношений являются цели, условия и средства достижения этой цели, определяющие ее, результаты отношения [15, с. 21].

\section{ВЫВОДЫ}

Современная политэкономия выработала общие подходы к исследованию категорий «труд» и «трудовые отношения». Труд характерен для всех сфер совокупного общественного производства (материальное, духовное, социальное производство и производство общественного человека). Имея свою специфику в каждой из названных взаимосвязанных и взаимозависимых сфер, труд выполняет функцию обеспечения жизненности отдельного человека и общества в целом, его (в идеале качественно расширенного) воспроизводства. Однако, рассматривая трудовые отношения как вид экономических отношений и отделяя их (абстрактно) от других блоков экономических и социальных отношений, в исследовании социально-экономических систем с позиции политэкономии определим трудовую деятельность как целесообразную деятельность субъекта, направленную на создание материальных средств и благ для обеспечения жизненности общества и его членов. 
Рассматривая трудовую деятельность как элемент системы трудовых отношений (как активность исходного элемента трудовых отношений, субъекта), отметим, что выбор или признаки этого субъекта определяют характер трудового отношения, а условия и средства - его цель и направленность. При исследовании трудовых отношений и управления ими прежде всего необходимо четко обозначить исследуемый субъект, в качестве которого может выступать как индивид, совокупность индивидов, класс, трудовой коллектив, трудовые ресурсы отрасли и т.д. При обозначении признаков субъекта и его места и роли в социально-экономической системе произойдет автоматическое сужение категории «труд» для целей конкретного исследования. По результатам проведенного исследования скорректируем понимание трудовых отношений как субъектобъектных, межсубъектных и внутрисубъектных отношений, которые возникают в процессе труда, выполняемого в целях создания материальных средств и благ для обеспечения жизненности общества и его членов.

\section{ЛИТЕРАТУРА}

1. Герасимов, Н.В. Экономическая система / Н.В. Герасимов. - Минск : Навука і тэхніка, 1991. - 349 с.

2. Никитенко, П.Г. Ноосферная экономика и социальная политика / П.Г. Никитенко. - Минск : Белорусская наука, 2006. -478 с.

3. Национальная стратегия устойчивого социально-экономического развития Республики Беларусь на период до 2020 г. [Электронный ресурс] // Режим доступа: http://un.by/pdf/OON_sMall_Rus.pdf. - Дата доступа: 16.10.2015.

4. Демографическая ситуация, человеческий и социальный капитал Республики Беларусь: системный анализ и оценка / [С.Ю. Солодовников и др.]. - Минск: Белорусская наука, 2008. - 423 с.

5. Статистический сборник «Труд и занятость в Республике Беларусь, 2006 (Стат.сб.) Минстат Республики Беларусь. - Минск, 2006. - 375 с.

6. Статистический сборник «Труд и занятость в Республике Беларусь, 2011 (Стат.сб.) Минстат Республики Беларусь. - Минск, 2011. - 348 с.

7. Статистический сборник «Труд и занятость в Республике Беларусь, 2014 (Стат.сб.) Минстат Республики Беларусь. - Минск, 2014. - 320 с.

8. Статистический сборник «Наука и инновационная деятельность в Республике Беларусь», 2010-2014 (Стат. Сб.) Минстат Республики Беларусь - Минск, 2015. - 138 с.

9. Наука Республики Беларусь: 1996. Стат.сб./ БелИСА - Минск, 1997. - 126 с.

10. Наука, инновации и технологии в Республике Беларусь 2009: Стат.сб.- Минск: ГУ «БелИСА», 2010.- 196 с.

11. Наука, инновации и технологии в Республике Беларусь 2006: Стат.сб.- Минск: ГУ «БелИСА», 2007.- 212 с.

12. Большая Советская Энциклопедия (в 30 томах). Гл. ред. А.М. Прохоров. Изд. 3-е. М.: Советская Энциклопедия, 1972. - Т.8. - 592 с.

13. Маркс, К., Энгельс, Ф. Соч. - 2-е изд. - Т. 23.

14. Морова, А.П. Социальная политика в сфере трудовых отношений / А.П. Морова. - Минск : ИСПИ, 2000. - 174 с.

15. Характер, структура и факторы формирования экономических отношений / Л.П. Васюченок [и др.]. - Минск: Навука і тэхніка, 1992. - 191 с.

Статья поступила в редакциию 22 декабря 2015 года. 